\title{
Exogenous Hydrogen Peroxide Induces Lipid Raft-Mediated STAT-6 Activation in T Cells
}

\author{
Hee Ja Kim ${ }^{\mathrm{a}}$ Jiwoo Lim ${ }^{\mathrm{a}}$ Young-Soon Jang ${ }^{\mathrm{b}}$ Eui-Cheol Shin ${ }^{\mathrm{b}}$ Hyung-Ran Kim ${ }^{\mathrm{c}}$ \\ Ju-Young Seoh ${ }^{c}$ Ji Soo Lee ${ }^{d}$ Soon Nam Lee ${ }^{e}$ Jihee Lee Kang ${ }^{a}$ Youn-Hee Choia \\ ${ }^{a}$ Department of Physiology, Tissue Injury Defense Research Center, Ewha Womans University School \\ of Medicine, Seoul, 'baboratory of Immunology and Infectious Diseases, Graduate School of Medical \\ Science and Engineering, KAIST, Daejeon, 'Department of Microbiology, Ewha Womans University \\ School of Medicine, Seoul, dDivision of Rheumatology, Department of Internal Medicine, Ewha Womans \\ University School of Medicine, Seoul, eDivision of Hematology-Oncology, Department of Internal \\ Medicine, Ewha Womans University School of Medicine, Seoul, Korea
}

\section{Key Words}

Reactive oxygen species (ROS) • IL-4 • STAT- 6 - Lipid rafts • Th2 cells

\begin{abstract}
Background/Aims: $C D 4+T$ cells are a critical component of the adaptive immune response. While the mechanisms controlling the differentiation of the Th1, Th17, and regulatory $T$ cell subsets from naïve $C D 4+T$ cells are well described, the factors that induce Th2 differentiation are still largely unknown. Methods: The effects of treatment with exogenous $\mathrm{H}_{2} \mathrm{O}_{2}$ on STAT- 6 phosphorylation and activation in T cells were examined by immunoblotting, immunofluorescence and gel shift assay. Anti-CD3 antibody and methyl- $\beta$-cyclodextrin were utilized to induce lipid raft assembly and to investigate the involvement of lipid rafts, respectively. Results: Jurkat and EL-4 T cells that were exposed to $\mathrm{H}_{2} \mathrm{O}_{2}$ showed rapid and strong STAT- 6 phosphorylation, and the extent of STAT- 6 phosphorylation was enhanced by co-treatment with anti-CD3 antibody. The effect of $\mathrm{H}_{2} \mathrm{O}_{2}$ on STAT- 6 phosphorylation and translocation was inhibited by disruption of lipid rafts. STAT- 6 activation in response to $\mathrm{H}_{2} \mathrm{O}_{2}$ treatment regulated IL-4 gene expression, and this response was strengthened by treatment with anti-CD3. Conclusion: Our results indicate that reactive oxygen species such as $\mathrm{H}_{2} \mathrm{O}_{2}$ can act on upstream and initiating factors for activation of STAT- 6 in T cells and contribute to formation of a positive feedback loop between STAT- 6 and IL-4 in the Th2 differentiation process.
\end{abstract}

Hee J. Kim and J. Lim contributed equally to this work.

Youn-Hee Choi

KARGER
Department of Physiology, Ewha Womans University School of Medicine, Mok-dong Yangcheon-gu, Seoul, 158-710 (Korea)

Tel. +82-2-2650-5838, Fax +82-2-2650-5717, E-Mail yc@ewha.ac.kr 


\section{Cellular Physiology Cell Physiol Biochem 2017;42:2467-2480

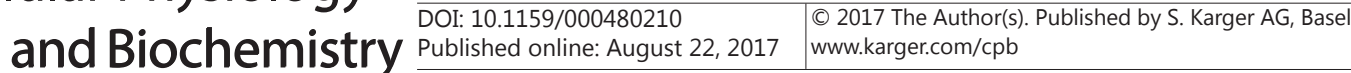 Kim et al.: $\mathrm{H}_{2} \mathrm{O}_{2}$ Activates STAT-6 in T Cells}

\section{Introduction}

Reactive oxygen species (ROS), such as superoxide $\left(\mathrm{O}_{2}^{-}\right)$, hydrogen peroxide $\left(\mathrm{H}_{2} \mathrm{O}_{2}\right)$, and hydroxyl radicals ( $\mathrm{HO} \bullet$ ), perform various functions in infection and inflammation [1]. Inflammatory cells generate large quantities of ROS at the site of inflammation, and the increase in ROS can initiate intracellular signaling that enhances pro-inflammatory gene expression [2]. Because ROS are intimately involved in various aspects of the immune response, ROS activity has implications for a wide variety of human disorders such as chronic inflammation, age-related diseases, and cancer [3,4].

$\mathrm{CD}^{+} \mathrm{T}$ cells are a crucial component of the adaptive immune responses [5]. Naïve $\mathrm{CD}^{+} \mathrm{T}$ cells can differentiate into at least four types of T helper cells, including Th1, Th2, Th17, and inducible regulatory $\mathrm{T}$ cells in response to various infectious agents, commensal microorganisms, self-antigens, and polarizing cytokines $[5,6]$. While the mechanisms controlling the differentiation of Th1, Th17, and regulatory T cell subsets are well described, the factors that induce Th2 differentiation are still being disputed [6]. A recent study showed that the innate cytokines interleukin (IL)-25, IL-33, and thymic stromal lymphopoietin (TSLP) play critical roles in Th2 immune responses [7]. IL-25, which is expressed by allergenactivated epithelial cells, acts directly on $\mathrm{CD} 4^{+} \mathrm{T}$ cells to initiate $\mathrm{Th} 2$ cell differentiation in an IL-4-dependent manner [8]. In addition, in the case of IL-33, one component of its receptor, ST2, is selectively expressed by Th2 cells and is involved in eosinophilic airway inflammation, as well as IL-4 and IL-5 expression [9-11]. Additionally, TSLP has been shown to play a crucial role in a model of Th2-mediated allergic skin inflammation by acting exclusively on $\mathrm{CD} 4^{+} \mathrm{T}$ cells [12].

Once naïve $\mathrm{CD}_{4}^{+} \mathrm{T}$ cells differentiate into Th2 cells, they can secrete IL-4, IL-5, and IL13 [7]. IL-4 is the major Th2 cytokine and plays a crucial role in the differentiation of Th2 cells $[5,6]$. These differentiation and proliferation processes are completely dependent on signal transducer and activator of transcription-6 (STAT-6) [13]. Binding of IL-4 to its receptor results in phosphorylation of STAT- 6 through activation of IL-4R-associated JAK kinases [14]. Phosphorylated STAT-6 dimerizes, translocates into the nucleus, and binds to DNA sequences, leading to transcriptional activation of Th2-relevant genes such as IL-4 [14]. In contrast to other STATs, which are activated by diverse stimuli, STAT-6 is largely unresponsive to cytokines and growth factors other than IL-4 and IL-13 [15]. STAT-6 is not only involved in the initiation of Th2 differentiation, but also contributes to maintenance of the Th2 phenotype by inducing the expression of chemokines and other Th2-relevant genes [6]. However, the factors that initiate the activation of STAT-6 in naïve T cells to promote the development of Th2 cells are largely unknown.

Lipid rafts contain several types of signaling molecules, and function as platforms for mediating a range of cellular events, including signal transduction, vesicular trafficking, and bacterial/viral entry/infection [16-19]. A number of studies have shown that hormones, bacteria, viruses, oxidative stress induced by ROS, and various receptors, such as CD95, CD40, EGFR, and TNFR exert their biological effects through lipid rafts [20-27]. Approximately $40 \%$ of the membranes of immune cells comprise lipid rafts; these rafts may be quite small in resting cells, but can be induced to coalesce into larger structures during cell activation, when the raft components become clustered through protein-protein and protein-lipid interactions [28]. In addition, lipid rafts aggregate at the site of T cell receptor (TCR) engagement and act as foci for triggering the signaling machinery in T cells [29]. Extensive crosslinking of TCR with anti-CD3 antibodies promotes rapid activation of Src kinases and the subsequent accumulation of a series of newly tyrosine-phosphorylated substrates in the rafts, including virtually all the hyperphosphorylated $\mathrm{CD} 3 \zeta$ isoforms, activated ZAP-70 tyrosine kinase and phospholipase $\mathrm{C} \gamma 1$ (PLC $\gamma 1$ ), phosphoinositide 3-kinase (PI3-K), exchange factors such as Vav, Rac/CDC42, and LAT [28].

In this study, we demonstrate that $\mathrm{H}_{2} \mathrm{O}_{2}$ affects the phosphorylation of STAT- 6 through lipid raft-mediated activation of Src family kinases (SFKs) in human and mouse T cell lines, and activated STAT- 6 promotes differentiation of naïve T cell by regulating gene expression 


\section{Cellular Physiology Cell Physiol Biochem 2017;42:2467-2480 \begin{tabular}{ll|l} 
DOI: 10.1159/000480210 & $\begin{array}{l}\text { O 2017 The Author(s). Published by S. Karger AG, Basel } \\
\text { www.karger.com/cpb }\end{array}$ \\
\hline
\end{tabular} \\ Kim et al.: $\mathrm{H}_{2} \mathrm{O}_{2}$ Activates STAT- 6 in T Cells}

of IL-4. We also show that STAT-6 activation by exogenous ROS is dependent on lipid raftmediated signaling pathways in T cells by providing evidence that the extents of STAT- 6 phosphorylation is dependents on the status of lipid rafts.

\section{Materials and Methods}

\section{Cell culture}

Jurkat cells (a human T-cell lymphoma cell line) and EL-4 cells (a murine T-cell lymphoma cell line) were grown in RPMI 1640 (Welgene, Daegu, Korea), containing 10\% (v/v) fetal bovine serum (FBS, Gibco, Grand Island, USA) supplemented with 100 units $/ \mathrm{ml}$ penicillin and $100 \mu \mathrm{g} / \mathrm{ml}$ streptomycin in a humidified $5 \% \mathrm{CO}_{2}$ incubator at $37^{\circ} \mathrm{C}[30]$.

\section{Mice and preparation of naïve $C D 4^{+} T$ cells}

C57BL/6 mice were housed and maintained in the animal facility at Ewha Womans University [31]. This study was performed according to the Korean Food and Drug Administration guidelines and was specifically approved by the Institutional Animal Care and Use Committee of Ewha Womans University Graduate School of Medicine (Permit Number: 10-0133). To prepare naïve CD4 ${ }^{+} \mathrm{T}$ cells, spleens were removed from sacrificed mice and a single cell suspension was prepared using a cell strainer $(70 \mu \mathrm{m}$, BD Biosciences, San Jose, CA, USA). After erythrocytes were lysed with RBC lysis buffer (eBioscience, San Diego, CA, USA), the CD4 ${ }^{+}$fraction was separated using a CD4 isolation kit purchased from Miltenyi biotech (Auburn, CA, USA).

\section{Reagents}

$\mathrm{H}_{2} \mathrm{O}_{2}, N$-acetylcysteine (NAC), catalase, JAK inhibitor AG490, Src family kinases inhibitor PP2, methyl$\beta$-cyclodextrin (M $\beta C D$ ), and cholesterol were purchased from Sigma-Aldrich (St. Louis, MO, USA). IFN- $\gamma$ and IL-4 were purchased from ProSpec (Rehovot, Israel). Antibodies against phospho-STAT-6 and phosphoSrc were obtained from Cell Signaling (Beverly, MA, USA) and anti-STAT- 6 antibody was obtained from Santa Cruz Biotechnology (Santa Cruz, CA, USA). Anti-CD3 antibody was obtained from BD Transduction Laboratories (Lexington, KY, USA). Fluorescein isothiocyanate-labeled cholera toxin B subunit (FITC-CTxB) and alpha tubulin antibody were obtained from Sigma-Aldrich. Horseradish peroxidase (HRP)-conjugated secondary antibodies for immunoblotting were obtained from Santa Cruz Biotechnology.

\section{Western blot analysis}

Cells were washed with phosphate-buffered saline (PBS) and lysed in ice-cold radioimmunoprecipitation assay (RIPA) buffer containing protease inhibitors, $1 \mathrm{mM}$ ethylenediaminetetraacetic acid (EDTA), and $0.5 \mathrm{mM} \mathrm{Na}_{3} \mathrm{VO}_{4}$ [32]. Cell lysates were centrifuged at $4^{\circ} \mathrm{C}$ for $30 \mathrm{~min}$ at $12,000 \times \mathrm{g}$ and the supernatant fractions were retained for immunoblot analysis. Poteins were separated by $8 \%$ sodium dodecyl sulfate polyacrylamide gel electrophoresis (SDS-PAGE) and transferred to polyvinylidene difluoride (PVDF) membranes. Membranes were soaked in blocking solution (Tris-buffered saline with $0.1 \%$ Tween 20 (TBST) containing 5\% skim milk) for $1 \mathrm{~h}$ at room temperature (RT) and probed with primary antibodies at a dilution of 1:1000 at $4^{\circ} \mathrm{C}$ overnight. After washing, the membranes were incubated with HRP-conjugated secondary antibodies at a dilution of 1:5000 for $1 \mathrm{~h}$ at RT. Immunoreactive signals were developed using an enhanced chemiluminescence (ECL) system (Amersham, Buckinghamshire, UK) and detected by exposure to X-ray film (Agfa, Belgium).

\section{Immunofluorescence assay}

Jurkat cells cultured on poly-D-lysine-coated coverslips were washed twice with ice-cold PBS and fixed in chilled $4 \%$ paraformaldehyde solution in PBS at $4^{\circ} \mathrm{C}$ for 30 min. Fixed cells were washed with PBS and blocked with $5 \%$ bovine serum albumin (BSA) for $1 \mathrm{~h}$ at RT, followed by three washes for 15 min each in PBS. Cells were then incubated with FITC-CTxB at a dilution of 1:100 in PBS for $1 \mathrm{~h}$ at RT. After washing, the cells were mounted in mounting solution (Molecular Probes, Eugene, OR, USA) containing 4',6-diamidino2-phenylindole (DAPI), and observed under a confocal microscope LSM 510 (Carl Zeiss, Oberkochen, Germany). For p-STAT-6 staining, Jurkat cells cultured on poly-D-lysine-coated coverslips were fixed in chilled $4 \%$ paraformaldehyde solution in PBS at $4^{\circ} \mathrm{C}$ for $30 \mathrm{~min}$ and then permeabilized with chilled methanol for 


\section{Cellular Physiology Cell Physiol Biochem 2017;42:2467-2480 \begin{tabular}{l|l|l} 
DOI: 10.1159/000480210 & and Biochemistry Published online: August 22, 2017 & $\begin{array}{l}\text { O 2017 The Author(s). Published by S. Karger AG, Basel } \\
\text { www.karger.com/cpb }\end{array}$ \\
\cline { 2 - 3 } &
\end{tabular} \\ Kim et al.: $\mathrm{H}_{2} \mathrm{O}_{2}$ Activates STAT- 6 in T Cells}

$10 \mathrm{~min}$, followed by three washes for $15 \mathrm{~min}$ each in PBS. Nonspecific protein binding was reduced by incubation in 5\% BSA for $2 \mathrm{~h}$ at RT. The cells were incubated with primary antibody (anti-p-STAT6, diluted 1:100) overnight at $4^{\circ} \mathrm{C}$, followed by secondary antibody (goat anti-rabbit ALEXA 568-conjugated, diluted 1:500) for $2 \mathrm{~h}$ at RT.

\section{Detergent-free discontinuous sucrose gradient ultracentrifugation}

Low-density membrane rafts were isolated using discontinuous sucrose gradient ultracentrifugation, as described previously [33]. Cells were washed twice with ice-cold PBS, scraped into $0.5 \mathrm{M}$ sodium carbonate ( $\mathrm{pH} 11.0$ ), and homogenized using a loose-fitting Dounce homogenizer ( $\sim 40$ strokes). The homogenate was adjusted to $40 \%$ sucrose by the addition of $2 \mathrm{ml}$ of $80 \%$ sucrose prepared in MBS (25 mM MES, pH 6.5, 0.15 $\mathrm{M} \mathrm{NaCl}$ ) and placed at the bottom of an ultracentrifuge tube. A 5\%/35\% discontinuous sucrose gradient (4

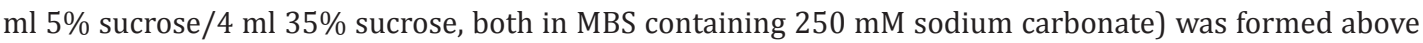
the sample and centrifuged at 190, 000×g for $20 \mathrm{~h}$ in a SW41 rotor (Beckman Instruments, Fullerton, CA, USA). From the top of each gradient, $1 \mathrm{ml}$ fractions were collected, yielding a total of 12 fractions. Gradient fractions were separated by SDS-PAGE on $8 \%$ gels and transferred to nitrocellulose membranes, which were subsequently blocked and incubated with anti-STAT- 6 antibody. To detect the GM1 ganglioside, $1 \mu \mathrm{l}$ of each flotation fraction was dot-blotted onto a nitrocellulose membrane. The membrane was air-dried, blocked with 5\% skim milk in TBST, and incubated with cholera toxin B subunit-peroxidase conjugate (CTxB-HRP) (Sigma-Aldrich). Immunoreactive proteins were detected by incubation in the ECL system (Amersham), followed by exposure to X-ray film.

\section{Treatment with $M \beta C D$}

$\mathrm{M} \beta \mathrm{CD}$, a cholesterol depleting agent, was used to investigate the involvement of lipid rafts. After treatment with 5-10 mM M $\beta C D$ for $30 \mathrm{~min}$, cells were treated with $1 \mathrm{mM} \mathrm{H}_{2} \mathrm{O}_{2}$ for $10 \mathrm{~min}$ in the presence or absence of $\alpha$-CD3 antibody and then harvested. To reassemble the lipid rafts, cells were treated with $8 \mathrm{mM}$ $\mathrm{M} \beta \mathrm{CD}$ for $30 \mathrm{~min}$, followed by treatment with $25 \mu \mathrm{M}$ water-soluble cholesterol for $30 \mathrm{~min}$.

\section{Nuclear extracts and electrophoretic mobility shift assays (EMSAs)}

EMSAs were performed as previously described [34]. Briefly, Jurkat cells treated with $1 \mathrm{mM} \mathrm{H}_{2} \mathrm{O}_{2}$ and/or $\alpha$-CD3 antibody for 10 min were harvested and suspended in $900 \mu$ l hypotonic solution (10 $\mathrm{mM}$ HEPES [pH 7.9], $10 \mathrm{mM} \mathrm{KCl,} 0.1 \mathrm{mM}$ EDTA, $0.1 \mathrm{mM}$ EGTA, $1 \mathrm{mM}$ DTT, $0.5 \mathrm{mM}$ PMSF) containing 0.5\% Nonidet P-40. Cells were centrifuged at $500 \times \mathrm{g}$ for $10 \mathrm{~min}$ at $4^{\circ} \mathrm{C}$, and the pellet (nuclear fraction) was saved. Nuclear extracts were incubated with the consensus STAT-6 sequence (Santa Cruz Biotechnology), which had been end-labeled with [ $\left.{ }^{32} \mathrm{P}\right]$ ATP, for 30 min. For competition experiments, a 100-molar excess of unlabeled oligonucleotide was added to the nuclear extracts for $30 \mathrm{~min}$ before addition of the labeled probe. For supershift experiments, nuclear extracts were incubated with $2 \mu \mathrm{g}$ anti-STAT-6 antibody (Santa Cruz Biotechnology) for $30 \mathrm{~min}$ before addition of the $\gamma^{-32} \mathrm{P}$-labeled probe. Bound and free DNA were then resolved by electrophoresis through a $6 \%$ polyacrylamide gel and exposed for autoradiography.

\section{Quantitative real-time PCR ( $q$ RT-PCR)}

Naïve CD4 ${ }^{+} \mathrm{T}$ cells were isolated from the spleen of C57BL/ 6 mice using a naïve $\mathrm{CD} 4^{+} \mathrm{T}$ cell isolation kit (Miltenyi Biotech) and were stimulated with $1 \mathrm{mM} \mathrm{H}_{2} \mathrm{O}_{2}$ for $10 \mathrm{~min}$ in the presence or absence of $\alpha$-CD3. Total cellular RNA was isolated using an RNA extract kit (Qiagen, Hilden, Germany) according to the manufacturer's protocol. Complementary DNA (cDNA) was synthesized using a High Capacity RNA-to-cDNA Kit (Applied Biosystems, Foster City, CA, USA). IL-4 messenger RNA (mRNA) was quantitated by real-time PCR with TaqMan Gene Expression Assays (Applied Biosystems, Foster City, CA) [35]. All PCR reaction samples were prepared in triplicate to determine $I L-4$ mRNA levels, which were normalized to an endogenous reference (glyceraldehyde-3phosphate dehydrogenase, GAPDH).

\section{Statistical analyses}

Student's t-test was used for comparisons between sample groups, and one-way analysis of variance (ANOVA) with Tukey's post hoc test was used to determine differences among multiple groups (SPSS 12.0 K for Windows, SPSS Inc., Chicago, IL, USA). The statistical significance level for the data was set at $P<0.05$. 


\section{Cellular Physiology Cell Physiol Biochem 2017;42:2467-2480 \begin{tabular}{ll|l} 
DOI: 10.1159/000480210 & $\begin{array}{l}\text { O 2017 The Author(s). Published by S. Karger AG, Basel } \\
\text { www.karger.com/cpb }\end{array}$ \\
and Biochemistry Published online: August 22, 2017
\end{tabular}

\section{Results}

$\mathrm{H}_{2} \mathrm{O}_{2}$ induces phosphorylation of STAT-6 in the Jurkat human T-cell lymphoma cell line

We initially examined the influence of $\mathrm{H}_{2} \mathrm{O}_{2}$ on STAT- 6 phosphorylation in the Jurkat human T-cell lymphoma cell line. The effects of treatment with exogenous $\mathrm{H}_{2} \mathrm{O}_{2}$ on STAT6 phosphorylation were examined by immunoblotting for p-STAT- $6 . \mathrm{H}_{2} \mathrm{O}_{2}$ induced a dosedependent increase in the level of tyrosine-phosphorylated STAT-6, up to a concentration of $1 \mathrm{mM}$, without altering the quantities of STAT- 6 or tubulin proteins (Fig. 1A). In Jurkat cells, STAT-6 phosphorylation increased in a dose-dependent manner, up to $5 \mathrm{mM} \mathrm{H}_{2} \mathrm{O}_{2}$ treatment (data not shown). IL-4 and IFN- $\gamma$ were used as positive controls for phosphorylation of STAT- 6 and STAT-1, respectively. Next, to confirm whether $\mathrm{H}_{2} \mathrm{O}_{2}$ has a direct effect on STAT6 phosphorylation, we treated Jurkat cells with catalase (Fig. 1B) or NAC (Fig. 1C). Both catalase and NAC reduced $\mathrm{H}_{2} \mathrm{O}_{2}$-mediated phosphorylation of STAT-6 in a dose-dependent manner.

\section{Different patterns of STAT-6 phosphorylation in response to $\mathrm{H}_{2} \mathrm{O}_{2}$ and IL-4}

Because both IL- 4 and $\mathrm{H}_{2} \mathrm{O}_{2}$ induced STAT- 6 phosphorylation in Jurkat cells, we performed a time-course analysis of STAT- 6 phosphorylation in response to $\mathrm{H}_{2} \mathrm{O}_{2}$ and IL-4. As shown in Fig. 2A, STAT-6 phosphorylation was detected at 10 min of $1 \mathrm{mM} \mathrm{H}_{2} \mathrm{O}_{2}$ treatment (lane 2),

Fig. 1. $\mathrm{H}_{2} \mathrm{O}_{2}$ induces STAT6 phosphorylation in Jurkat cells. (A) Jurkat cells were treated with the indicated concentrations of $\mathrm{H}_{2} \mathrm{O}_{2}$ (0-1 $\mathrm{mM})$ for $10 \mathrm{~min}, \mathrm{hIL}-4$ (10 ng/ml), or IFN- $\gamma(10 \mathrm{ng} /$ $\mathrm{ml}$ ) for $30 \mathrm{~min}$. Whole cell lysates extracted and analyzed by immunoblotting (left). Blots were probed with antibodies against p-STAT-6, total STAT-6, pSTAT-1, total STAT-1, and

A
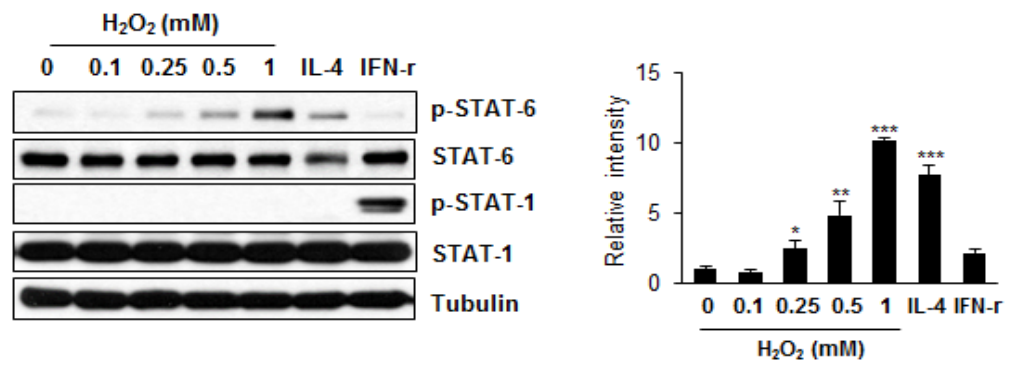

B

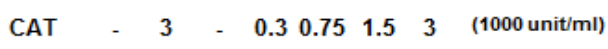
$\mathrm{H}_{2} \mathrm{O}_{2}$

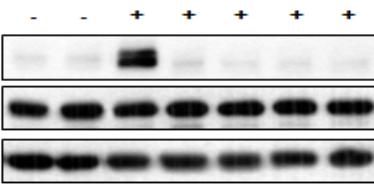
p-STAT-6 STAT-6 Tubulin

C

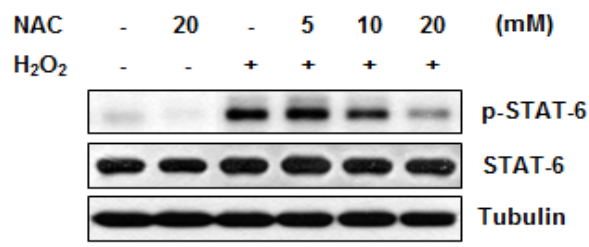
tubulin. The graph shows the intensity of p-STAT- 6 normalized against that of tubulin, determined in three independent experiments (right). ${ }^{*} \mathrm{P}<0.05,{ }^{* *} \mathrm{P}<0.01,{ }^{* * *} \mathrm{P}<0.001$ vs. untreated control cells. $(\mathrm{B}, \mathrm{C})$ Jurkat cells were treated with $1 \mathrm{mM} \mathrm{H}_{2} \mathrm{O}_{2}$ for $10 \mathrm{~min}$ in the presence or absence of different amounts of catalase (B) or NAC (C), and the STAT-6 phosphorylation level was analyzed by immunoblotting. Data are representative of at least three experiments. P, phospho. 
remained high at $30 \mathrm{~min}$ (lane 3 ), decreased at $60 \mathrm{~min}$ (lane 4), and then diminished by $120 \mathrm{~min}$ (lane 5). In contrast, in response to IL-4, STAT-6 phosphorylation was detected at $10 \mathrm{~min}$ (Fig. $2 \mathrm{~B}$, lane 2), remained high at 30 min (lane 3), decreased from 60-120 min (lanes 4 and $5)$, and then was re-induced by 240 min (lane 6). To investigate which upstream kinase was involved in $\mathrm{H}_{2} \mathrm{O}_{2}$-induced STAT-6 phosphorylation, we pretreated Jurkat cells with the JAKinhibitor AG490 and the Src family kinases inhibitor PP2 in the presence of $\mathrm{H}_{2} \mathrm{O}_{2}$ and IL-4 (Fig. 2C). Pretreatment with the PP2 suppressed the $\mathrm{H}_{2} \mathrm{O}_{2}$-induced phosphorylation of STAT- 6 but failed to suppress IL-4-induced STAT-6 phosphorylation (lanes 5 and 8). In contrast, following pretreatment with AG490, IL-4induced STAT-6 phosphorylation was completely abrogated, whereas $\mathrm{H}_{2} \mathrm{O}_{2}$-induced STAT6 phosphorylation was barely affected (lanes 6 and 9). These results indicate that $\mathrm{H}_{2} \mathrm{O}_{2}$ directly induces STAT-6 phosphorylation in Jurkat cells in the early time course (within 1 hour), mainly through SFKs.

\section{$\mathrm{H}_{2} \mathrm{O}_{2} \quad$ induces phosphorylation of STAT- 6 in the EL-4 murine T-cell lymphoma cell line \\ To examine the effect of $\mathrm{H}_{2} \mathrm{O}_{2}$} on STAT-6 phosphorylation in murine $\mathrm{T}$ cell, we used the EL-4 murine T-cell lymphoma cell line. Similar to the observation in Jurkat cells, in the EL-4 cells $\mathrm{H}_{2} \mathrm{O}_{2}$ induced a dose-dependent increase in the level of tyrosinephosphorylated STAT-6, up to a concentration of $1 \mathrm{mM}$, with no changes in the amount of STAT-6 or tubulin proteins (Fig. 3A). Dose-dependent increase of STAT-6 phosphorylation
A

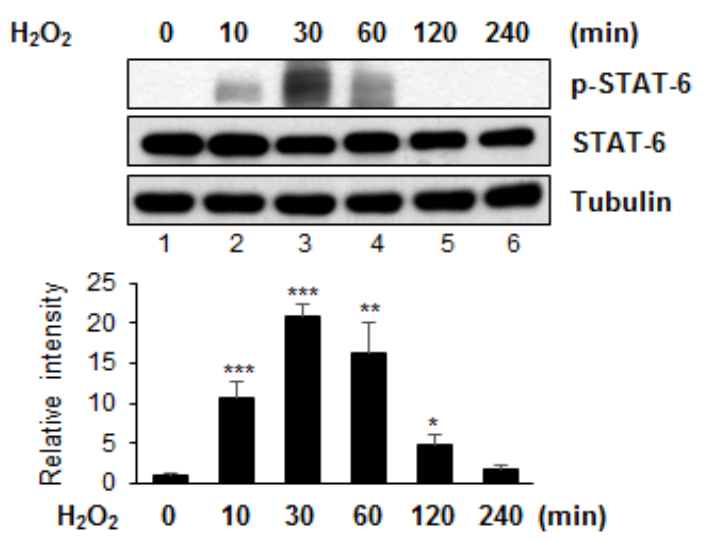

B
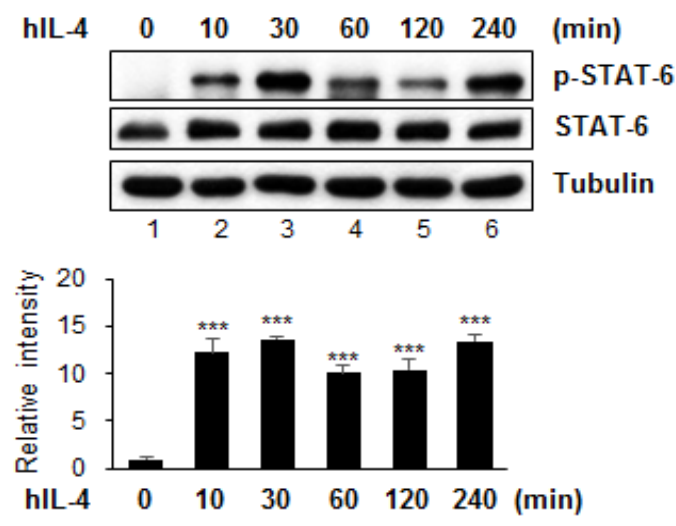

C

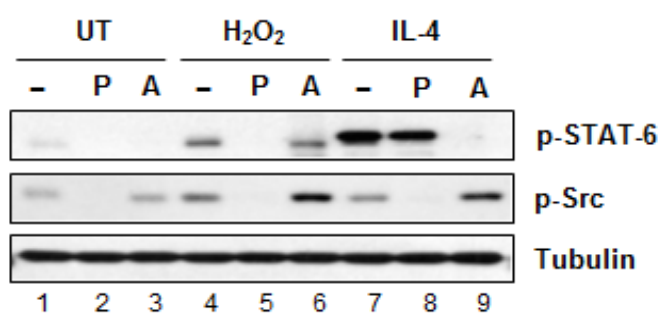

Fig. 2. Different patterns of STAT-6 phosphorylation in response to $\mathrm{H}_{2} \mathrm{O}_{2}$ and IL-4. (A, B) Jurkat cells were treated with $1 \mathrm{mM} \mathrm{H}_{2} \mathrm{O}_{2}$ (A) or $10 \mathrm{ng} / \mathrm{ml} \mathrm{hIL-4} \mathrm{(B)} \mathrm{for} \mathrm{the} \mathrm{indicated} \mathrm{times,} \mathrm{and} \mathrm{analyzed}$ by immunoblotting with anti-p-STAT-6, STAT-6, and anti-tubulin antibodies. The graph shows the intensity of p-STAT- 6 normalized against that of tubulin, determined in three independent experiments. ${ }^{*} \mathrm{P}<0.05$, ${ }^{* *} \mathrm{P}<0.01,{ }^{* * *} \mathrm{P}<0.001$ vs. untreated control cells. (C) Jurkat cells were incubated with $1 \mathrm{mM} \mathrm{H}_{2} \mathrm{O}_{2}$ or $10 \mathrm{ng} /$ ml hIL-4 in the presence or absence of PP2 or AG490, and whole cell lysates were analyzed by immunoblotting. Blots were probed with antibodies against p-STAT-6, p-Src, and tubulin. Data are representative of at least three experiments. P, phospho; P, PP2; A, AG490 pretreatment. 
was detected at $5 \mathrm{mM} \mathrm{H}_{2} \mathrm{O}_{2}$ treatment, similar to Jurkat cells (data not shown). STAT-6 phosphorylation was detected at $10 \mathrm{~min}$ of $1 \mathrm{mM} \mathrm{H}_{2} \mathrm{O}_{2}$ treatment (Fig. 3B, lane 2), peaked at $30 \mathrm{~min}$ (lane 3), decreased at $60 \mathrm{~min}$ (lane 4), and then diminished by $120 \mathrm{~min}$ (lane 5). In contrast, in response to IL-4, a binary pattern of STAT- 6 phosphorylation induction was detected, peaking at $10 \mathrm{~min}$ (Fig. 3C, lane 2), decreasing from 30-60 min (lanes 3 and 4), and then re-induced by 120 min (lane 6).

\section{$\mathrm{H}_{2} \mathrm{O}_{2}$-induced STAT-6 phosphorylation is mediated via lipid rafts}

We have reported that, in brain astrocytes, $\mathrm{H}_{2} \mathrm{O}_{2}$ administration results in activation of signaling pathways by inducing protein phosphorylation via lipid rafts [33, 36, 37]. To ascertain whether lipid rafts are involved in $\mathrm{H}_{2} \mathrm{O}_{2}$-induced phosphorylation of STAT- 6 in T cells, we pretreated Jurkat cells with methyl- $\beta$-cyclodextrin $(\mathrm{M} \beta \mathrm{CD})$, a cholesterol depleting agent that disrupts the integrity of lipid rafts. M $\beta C D$ administration profoundly inhibited $\mathrm{H}_{2} \mathrm{O}_{2}$-induced STAT-6 phosphorylation in a dose-dependent manner (Fig. 4A, lanes 3 and 4). To confirm that $\mathrm{H}_{2} \mathrm{O}_{2}$ and $\mathrm{M} \beta C D$ induced raft formation and disruption, respectively, in Jurkat cells, immunofluorescence was employed using fluorescein isothiocyanate-labeled cholera toxin B subunit (FITC-CTXB), which interacts with gangliosides in the plasma membrane. Immunofluorescence imaging of Jurkat cells stained with FITC-CTxB (green) revealed a strong patch-like pattern in the plasma membrane in the presence of $\mathrm{H}_{2} \mathrm{O}_{2}$ (Fig. $4 \mathrm{~B}$, arrowhead). Pretreatment with $\mathrm{M} \beta \mathrm{CD}$ completely abrogated the formation of patch-like domains in response to $\mathrm{H}_{2} \mathrm{O}_{2}$. Because it has been reported that the stimulation of the TCR-

Fig. 3. $\mathrm{H}_{2} \mathrm{O}_{2}$ induces phosphorylation of STAT-6 in EL-4 cells. (A) EL-4 cells were treated with the indicated concentrations of $\mathrm{H}_{2} \mathrm{O}_{2}$ (0-1 mM) for $10 \mathrm{~min}, \mathrm{mIL}-4$ (10 ng/ $\mathrm{ml})$, or $\mathrm{mIFN}-\gamma(10$ $\mathrm{ng} / \mathrm{ml}$ ) for $30 \mathrm{~min}$. Whole cell lysates were extracted and analyzed by immunoblotting. Blots were probed with antibodies against p-STAT-6, total STAT-6, p-STAT-1, total STAT-1, and tubulin. (B, C) EL-4 cells were treated with 1 $\mathrm{mM} \mathrm{H}_{2} \mathrm{O}_{2}$ (B) or $10 \mathrm{ng} /$ $\mathrm{ml} \mathrm{mIL-4} \mathrm{(C)} \mathrm{for} \mathrm{the}$ indicated times, and analyzed by immunoblotting with antip-STAT-6, STAT-6, and anti-tubulin antibodies. The graph shows the intensity of p-STAT-6 normalized against that of tubulin, determined in three independent experiments (right). ${ }^{*} \mathrm{P}<0.05,{ }^{* *} \mathrm{P}<0.01,{ }^{* * *} \mathrm{P}<0.001$ vs. untreated control cells. $\mathrm{P}$, phospho.
A
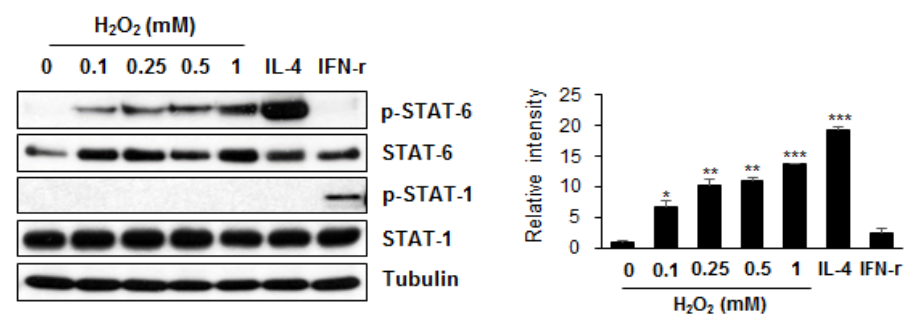

B
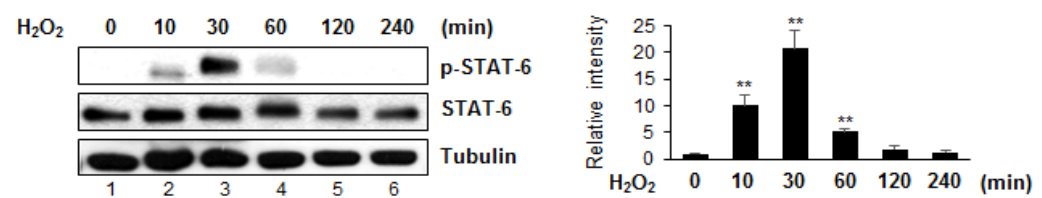

C
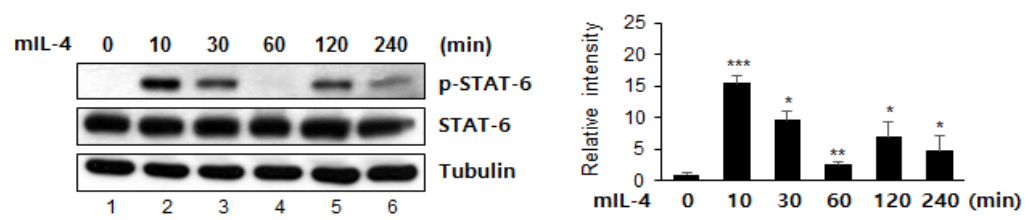


\section{Cellular Physiology Cell Physiol Biochem 2017;42:2467-2480

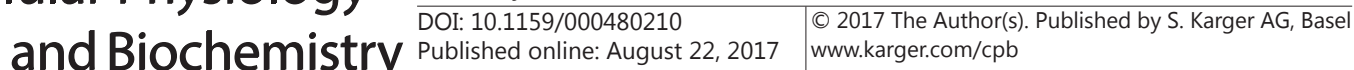 \\ Kim et al.: $\mathrm{H}_{2} \mathrm{O}_{2}$ Activates STAT-6 in T Cells}

CD3 complex with anti-CD3 antibody rapidly induces lipid raft assembly in T cells [38, 39], we tested the effect of CD3 engagement on $\mathrm{H}_{2} \mathrm{O}_{2}$-induced STAT- 6 phosphorylation. Interestingly, $\mathrm{H}_{2} \mathrm{O}_{2}$-induced STAT- 6 phosphorylation was significantly enhanced by stimulation with antiCD3 antibody in both Jurkat cells (Fig. 4C) and EL-4 cells (Fig. 4D). As shown in Figs. 5A and $5 \mathrm{~B}, \mathrm{M} \beta \mathrm{CD}$ also inhibited $\mathrm{H}_{2} \mathrm{O}_{2}$-induced phosphorylation of STAT- 6 in the presence of antiCD3 antibody in both cell lines. Addition of exogenous cholesterol to M $\beta C D$-treated cells restored $\mathrm{H}_{2} \mathrm{O}_{2}$-induced STAT-6 phosphorylation (Fig. 5C). These results indicate that STAT-6 phosphorylation in response to $\mathrm{H}_{2} \mathrm{O}_{2}$ occurs via lipid rafts, and CD3 engagement potentiates raft-mediated phosphorylation of STAT-6.

\section{$\mathrm{H}_{2} \mathrm{O}_{2}$ induces translocation of STAT-6 into lipid rafts}

The tyrosine residues of several membranous and cytoplasmic proteins are known to become phosphorylated as a result of associated with and/or recruitment to lipid rafts [40]. To test whether $\mathrm{H}_{2} \mathrm{O}_{2}$ induces recruitment of STAT- 6 proteins to lipid rafts in T cells, a detergent-free sucrose gradient centrifugation procedure was used. Fractions containing lipid rafts were detected by immunoblotting using cholera toxin B subunit conjugate horseradish peroxidase (CTxB-HRP), which binds to GM-1, a major components of lipid rafts. GM-1 was mainly detected in fractions 4 and 5, signifying the presence of lipid rafts (Fig. 6). More STAT-6 was detected in the GM-1-positive fractions from $\mathrm{H}_{2} \mathrm{O}_{2}$-treated cells than

Fig. 4. $\mathrm{H}_{2} \mathrm{O}_{2}$-induced STAT-6 phosphorylation is mediated via lipid rafts. (A) Jurkat cells were treated with $1 \mathrm{mM} \mathrm{H}_{2} \mathrm{O}_{2}$ for $10 \mathrm{~min}$, with or without $M \beta C D$, and then lysed with lysis buffer. Cell lysates were analyzed by immunoblotting with antip-STAT-6, anti-STAT-6, antitubulin antibodies. (B) Jurkat cells were treated with $1 \mathrm{mM} \mathrm{H}_{2} \mathrm{O}_{2}$ in the presence or absence $\mathrm{M} \beta \mathrm{CD}$, and then stained with a fluorescein isothiocyanate-labeled cholera toxin B subunit (FITCCTxB) to identify lipid rafts (green fluorescence) and with DAPI to identify nuclei. (C) Jurkat cells were treated with the indicated concentrations of $\mathrm{H}_{2} \mathrm{O}_{2}(0-5 \mathrm{mM})$ in the presence or absence of $\alpha$-CD3, and whole cell lysates were extracted and analyzed by immunoblotting (upper). Blots were probed with antibodies against p-STAT-6, total STAT-6, and tubulin. The graph shows the intensity of p-STAT-6 normalized against that of tubulin, determined in three independent experiments (lower). Data shown are representative of at least three experiments. (D) EL-4 cells were treated with the indicated concentrations of $\mathrm{H}_{2} \mathrm{O}_{2}(0-1 \mathrm{mM})$ in the presence or absence of $\alpha$-CD3, as described in (C). P, phospho; MCD, M $\beta C D$.

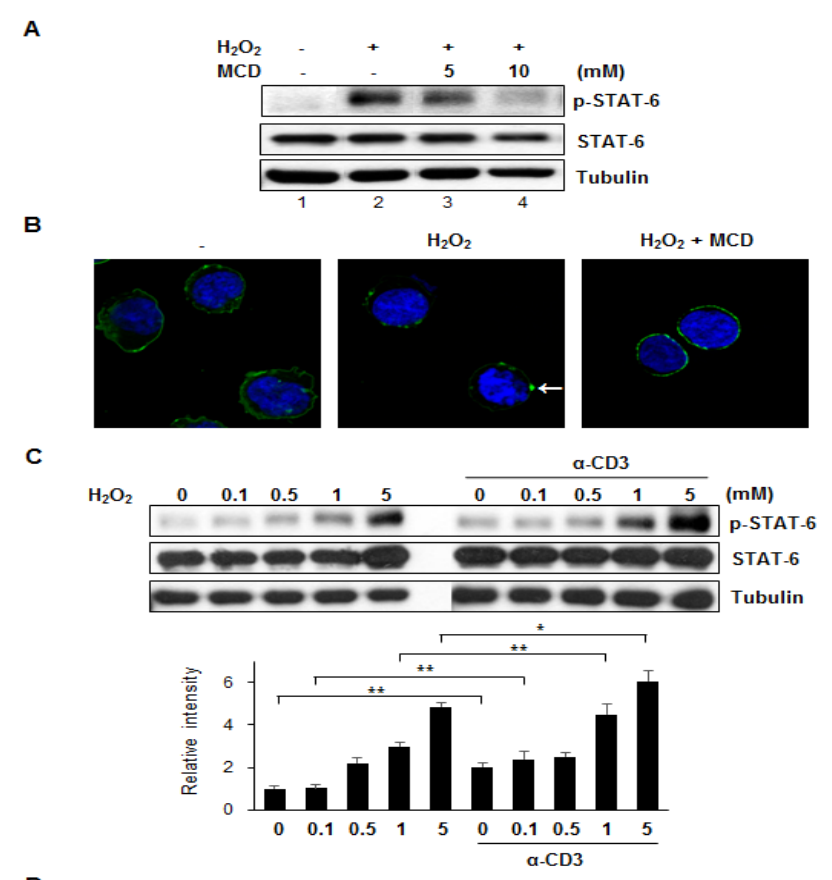

D

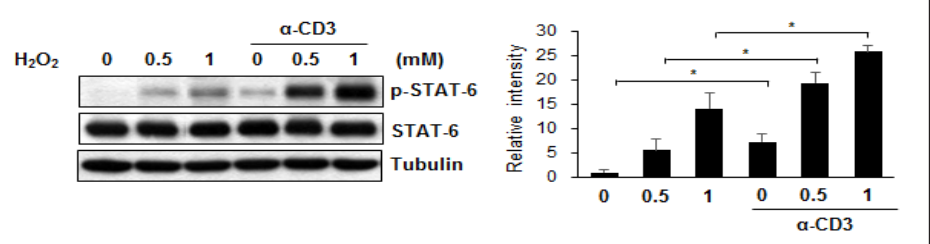




\section{Cellular Physiology

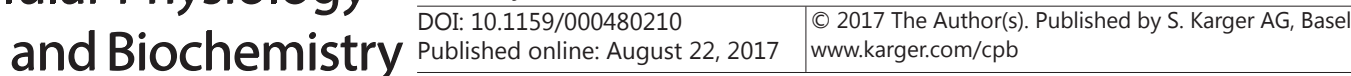

Fig. 5. $M \beta C D$ inhibits the amplifying effect of $\alpha$-CD3 on $\mathrm{H}_{2} \mathrm{O}_{2}$-induced STAT-6 phosphorylation. $(A, B)$ Jurkat cells $(A)$ and EL-4 cells (B) were treated with $1 \mathrm{mM} \mathrm{H}_{2} \mathrm{O}_{2}$ for $10 \mathrm{~min}$ and/or $\alpha$-CD3 in the presence or absence of different amounts of $\mathrm{M} \beta \mathrm{CD}$ and analyzed by immunoblotting with both anti-p-STAT-6 and anti-tubulin antibodies. The graph shows the intensity of p-STAT-6 normalized against that of tubulin, determined in three independent experiments (lower). The experiment was repeated at least three times, with similar results. (C) Cells pretreated with $8 \mathrm{mM}$ $\mathrm{M} \beta \mathrm{CD}$ for $30 \mathrm{~min}$ were treated with $25 \mu \mathrm{M}$ water-soluble cholesterol, 1 $\mathrm{mM} \mathrm{H}_{2} \mathrm{O}_{2}$ and/or $5 \mu \mathrm{g} / \mathrm{ml}$

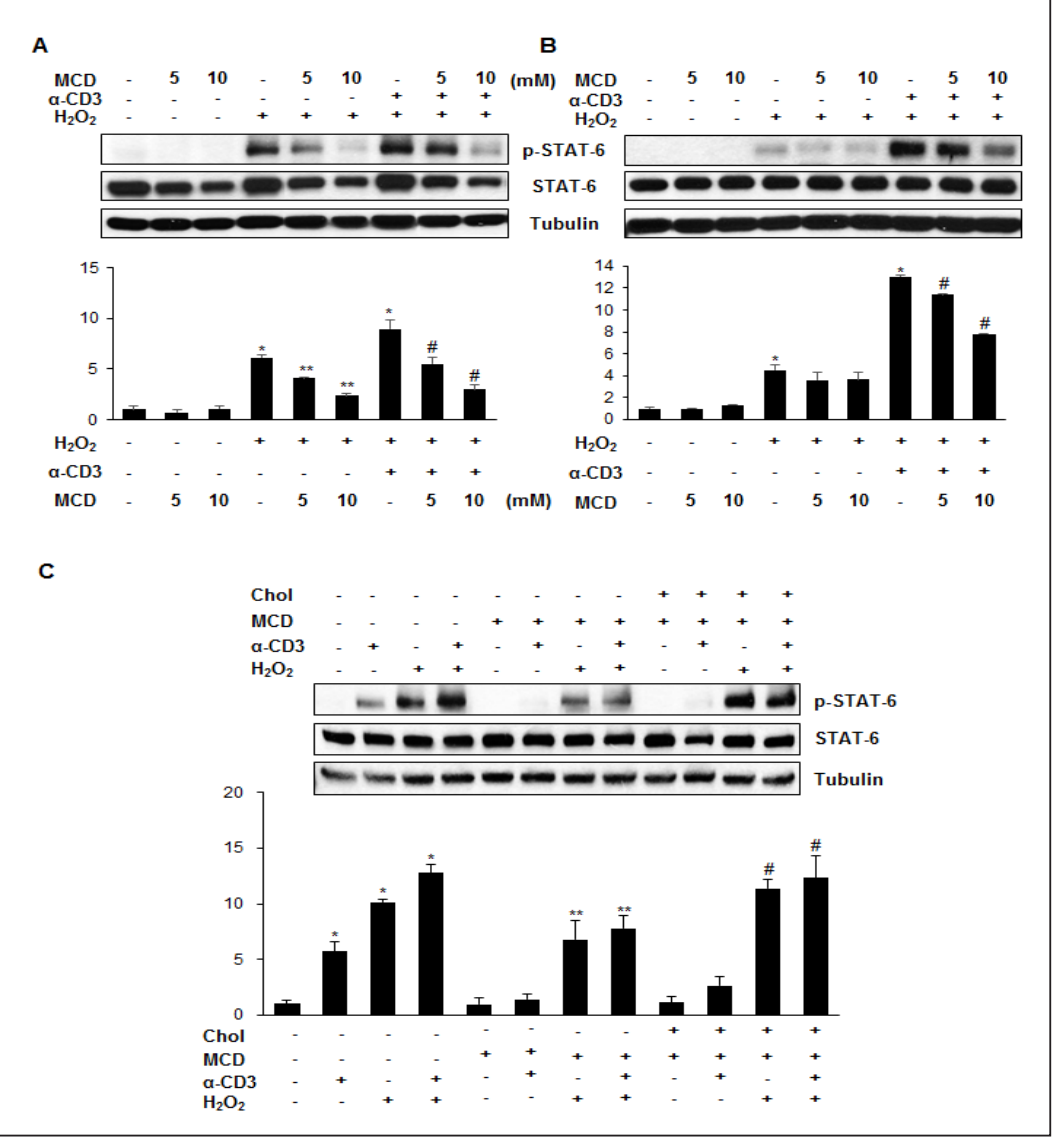
$\alpha$-CD3 for 10 min as indicated. Phosphorylation of STAT- 6 was confirmed by immunoblotting. P, phospho; $\mathrm{MCD}, \mathrm{M} \beta \mathrm{CD}$.

those from untreated cells, implying that protein translocation into lipid rafts was enhanced. Moreover, stimulation with anti-CD3 antibody in the presence of $\mathrm{H}_{2} \mathrm{O}_{2}$ further increased STAT- 6 translocation, compared to $\mathrm{H}_{2} \mathrm{O}_{2}$-treated cells. Pretreatment with $\mathrm{M} \beta \mathrm{CD}$ completely inhibited $\mathrm{H}_{2} \mathrm{O}_{2}$ - and $\mathrm{H}_{2} \mathrm{O}_{2}$ plus anti-CD3 antibody-induced STAT- 6 translocation, similar to its effects on STAT-6 phosphorylation. Thus, $\mathrm{H}_{2} \mathrm{O}_{2}$-induced phosphorylation and translocation of STAT- 6 in the presence or absence of anti-CD3 antibody was inhibited under conditions of raft disruption.

\section{$\mathrm{H}_{2} \mathrm{O}_{2}$-induced STAT-6 activation is functional}

Following tyrosine phosphorylation of STAT-6, the now-active STAT-6 homodimerizes, translocates into the nucleus, and binds to a DNA sequence, leading to the transcriptional activation of several STAT-6-regulated genes, including IL-4 [41]. To investigate whether $\mathrm{H}_{2} \mathrm{O}_{2}$ induced phosphorylation of STAT- 6 is functional, Jurkat cells were incubated in the absence or presence of $\mathrm{H}_{2} \mathrm{O}_{2}$ for 10 min, fixed, and then stained for p-STAT-6 (Fig. 7A, red). P-STAT-6 was rarely detected in the absence of $\mathrm{H}_{2} \mathrm{O}_{2}$, whereas $\mathrm{H}_{2} \mathrm{O}_{2}$ or $\mathrm{H}_{2} \mathrm{O}_{2}$ plus anti-CD3 antibody treatment enhanced p-STAT-6 localization to the nucleus as well as cytoplasm. Staining with isotype control antibodies was performed to verify specificity (data not shown). We then further assessed $\mathrm{H}_{2} \mathrm{O}_{2}$-induced STAT-6 DNA binding (Fig. 7B). STAT-6 DNA binding was induced by $\mathrm{H}_{2} \mathrm{O}_{2}$ treatment (lane 4) and further enhanced by $\mathrm{H}_{2} \mathrm{O}_{2}$ plus anti-CD3 antibody treatment (lane 5), but not by anti-CD3 antibody alone (lane 3). Competition with excess unlabeled oligonucleotide abrogated complex formation (lane 6). Anti-p-STAT-6 and STAT6 antibodies supershifted the complex (lanes 7 and 8), confirming the specific interaction between STAT- 6 and the STAT- 6 consensus sequence. We next examined the effect of $\mathrm{H}_{2} \mathrm{O}_{2}$ 


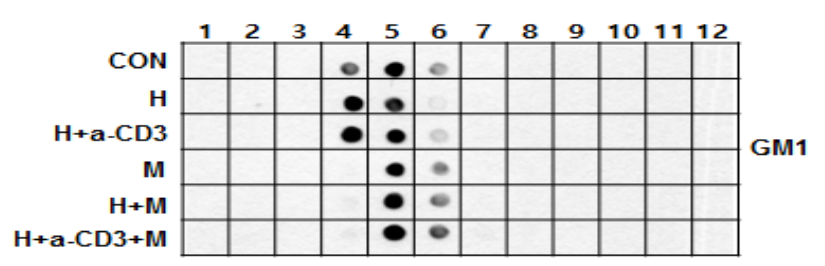

$\begin{array}{llllllllllll}1 & 2 & 3 & 4 & 5 & 6 & 7 & 8 & 9 & 10 & 11 & 12\end{array}$

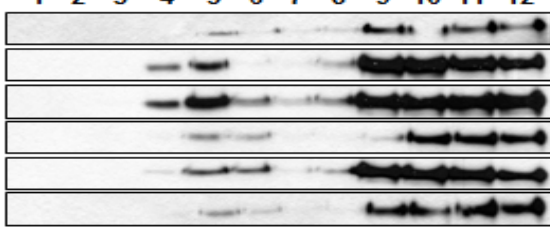

T-STAT-6 $\begin{array}{llllllllllll}1 & 2 & 3 & 4 & 5 & 6 & 7 & 8 & 9 & 10 & 11 & 12\end{array}$
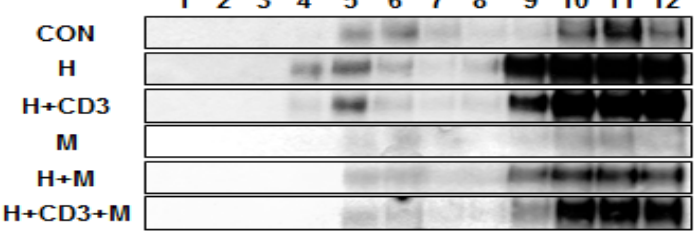

p-STAT-6

Fig. 6. $\mathrm{H}_{2} \mathrm{O}_{2}$ induces translocation of STAT- 6 into lipid rafts. Cells were incubated in the presence or absence of $1 \mathrm{mM} \mathrm{H}_{2} \mathrm{O}_{2}$ for $10 \mathrm{~min}$ with or without pretreatment with $\alpha$-CD3 and/or M $\beta C D$ for $30 \mathrm{~min}$. After homogenization, the sucrose concentration was adjusted and the homogenate was separated by 5\%/35\% discontinuous sucrose gradient centrifugation, as described in the Materials and Methods. The lipid raft marker, GM-1, was detected by dotting each fraction onto a nitrocellulose membrane and incubating with cholera toxin B-horseradish peroxidase, which binds to GM-1. On the basis of GM-1 reactivity, fractions 4 and 5 were identified as the predominant lipid-raft-containing fractions. Each fraction was analyzed by western blotting using anti-STAT- 6 and p-STAT-6 antibodies. Data are representative of at least three independent experiments. $\mathrm{H}_{2} \mathrm{H}_{2} \mathrm{O}_{2} ; \mathrm{M}, \mathrm{M} \beta \mathrm{CD}$.

Fig. 7. $\mathrm{H}_{2} \mathrm{O}_{2}$ induces IL-4 gene expression through STAT-6 activation. (A) Cells were incubated in the presence or absence of $1 \mathrm{mM} \mathrm{H}_{2} \mathrm{O}_{2}$ and/or $\alpha$-CD3 for $10 \mathrm{~min}$, and then stained for p-STAT-6. (B) Nuclear extracts from Jurkat cells treated with $\mathrm{H}_{2} \mathrm{O}_{2}$ and/or $\alpha$-CD3 were analyzed with a radiolabeled DNA probe for STAT-6. (C) Naïve T cells originating from mouse spleens were treated with $\mathrm{H}_{2} \mathrm{O}_{2}$ in the presence or absence $\alpha$-CD3. IL- 4 mRNA expression was analyzed by real-time PCR.

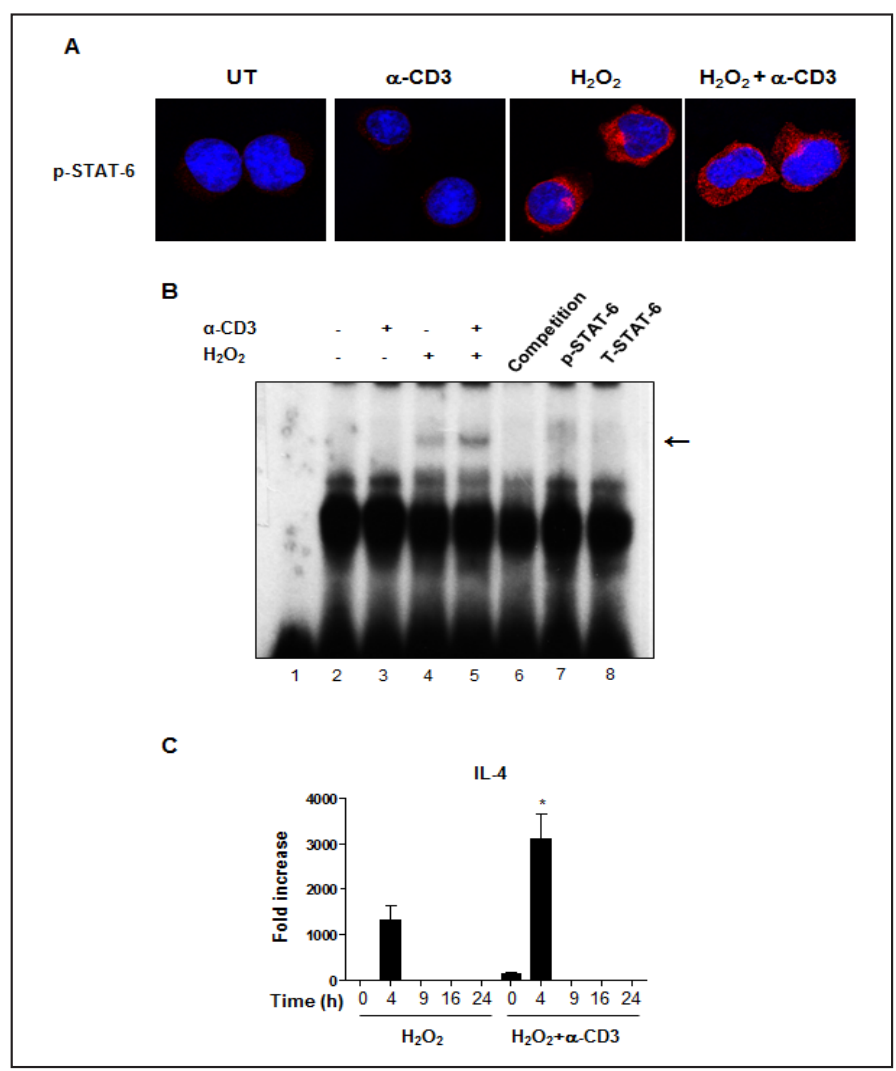




\section{Cellular Physiology Cell Physiol Biochem 2017;42:2467-2480 \\ \begin{tabular}{l|l} 
DOI: 10.1159/000480210 & and Biochemistry \\
Published online: August 22, 2017 & $\begin{array}{l}\text { O 2017 The Author(s). Published by S. Karger AG, Basel } \\
\text { www.karger.com/cpb }\end{array}$
\end{tabular} \\ Kim et al.: $\mathrm{H}_{2} \mathrm{O}_{2}$ Activates STAT-6 in T Cells}

or $\mathrm{H}_{2} \mathrm{O}_{2}$ plus anti-CD3 antibody treatment on STAT-6-regulated gene expression. Because we found that $\mathrm{H}_{2} \mathrm{O}_{2}$-induced STAT- 6 phosphorylation was strongly detected through 60 min and then diminished by 120 min in Jurkat and EL-4 cells (Figs. 2B and 3B), we next investigated the time-course of IL-4 mRNA expression in response to $\mathrm{H}_{2} \mathrm{O}_{2}$ in the absence or presence of anti-CD3 antibody in naïve T cells isolated from mouse spleen. The mRNA expression of IL-4 was validated using real-time PCR (Fig. 7C). mRNA expression of IL-4 was induced within 4 $\mathrm{h}$ after $\mathrm{H}_{2} \mathrm{O}_{2}$ treatment. A further increase in mRNA expression of IL-4 was observed in $\mathrm{H}_{2} \mathrm{O}_{2}$ plus anti-CD3 antibody-treated T cells at $4 \mathrm{~h}$. Interestingly, IL- 4 mRNA was not detected at later time points, from 9-24 h. These data indicate that $\mathrm{H}_{2} \mathrm{O}_{2}$ can initiate IL-4 gene expression in the early time course, through activation of the STAT- 6 signaling pathway.

\section{Discussion}

In this study, we demonstrated that exogenous treatment with $\mathrm{H}_{2} \mathrm{O}_{2}$ induces phosphorylation and activation of STAT- 6 via lipid rafts in human Jurkat T cells and mouse EL-4 T cells. We found that the kinetics of STAT- 6 phosphorylation by $\mathrm{H}_{2} \mathrm{O}_{2}$ and IL-4 differed with respect to time, although both $\mathrm{H}_{2} \mathrm{O}_{2}$ and IL-4 induced STAT- 6 phosphorylation. Interestingly, $\mathrm{H}_{2} \mathrm{O}_{2}$ only induced STAT- 6 phosphorylation in the early time course (within 1 hour) in Jurkat cells and EL-4 cells via lipid rafts-mediated SFKs activation, without later activation of STAT-6.

The IL-4 signaling cascade initiated by STAT- 6 activation is considered the canonical pathway of Th2 differentiation in T cells [42]. Typically, binding of IL-4 to its receptor results in activation of JAK and subsequent STAT-6 phosphorylation, dimerization, and nuclear translocation, leading to transcriptional activation of IL-4 and subsequent production of additional IL-4 via a positive feedback loop [6, 42]_ENREF_19. In contrast to $\mathrm{H}_{2} \mathrm{O}_{2}$, IL-4 induced STAT- 6 phosphorylation in a bimodal fashion, with early and late peaks (Figs. 2 and 3 ). This is consistent with other reports showing that IL-4 induces further IL-4 production, which contributes to Th2 polarization through STAT-6 activation [13]. IL-4 is essential for Th2 differentiation, but the cellular source of IL-4 that initiates development of naïve CD4 ${ }^{+}$ $\mathrm{T}$ cells into IL-4 expressing Th2 cells is not yet well defined. A recent study demonstrated that exposure of $\mathrm{CD}^{+} \mathrm{T}$ cells to 2, 3-dimethoxy-1, 4-naphthoquinone (DMNQ), which generates superoxide anions, led to upregulation of Th2-specific cytokines such as IL-4, IL-5, and IL-13 [43]. While oxidative stress promotes phosphorylation and activation of STAT- 6 and differentiation towards a Th2 phenotype in $\mathrm{CD} 4^{+} \mathrm{T}$ cells, which has been studied by several groups, the precise molecular mechanisms of the upstream and initiating factors in the activation of STAT- 6 and increase in IL- 4 and Th2 differentiation has not been welldefined. To the best of our knowledge, this is the first report to address the effect of $\mathrm{H}_{2} \mathrm{O}_{2}$ on STAT-6 phosphorylation and Th2 polarization by activation of SFKs pathways via functional lipid rafts in T cells. In our system, $\mathrm{H}_{2} \mathrm{O}_{2}$ seemed to be a strong stimulator of STAT6 phosphorylation and activation, which trigger naïve $\mathrm{T}$ cells to become IL-4-producing cells. Our results provide additional evidence that $\mathrm{H}_{2} \mathrm{O}_{2}$ induces tyrosine phosphorylation and functional activation of STAT-6, which becomes an active component of initiation of Th2specific signaling pathways in T cells.

While most endogenous ROS are produced by the mitochondria, exogenous ROS are generated from in vivo inhaled particles via the respiratory tract [44]. Although exogenous $\mathrm{H}_{2} \mathrm{O}_{2}$ can diffuse through membranes, native membranes act as significant barriers against $\mathrm{H}_{2} \mathrm{O}_{2}$ and many membranes are poorly permeable to $\mathrm{H}_{2} \mathrm{O}_{2}$ [45]. Recently, it has been proposed that $\mathrm{H}_{2} \mathrm{O}_{2}$ is transported to the intracellular spaces, at least in some cells, through membrane transporters such as aquaporin; $\mathrm{H}_{2} \mathrm{O}_{2}$ can initiate activation of many receptors by mimicking the action of the ligands, leading to activation of signaling molecules across the plasma membrane [3]. In our system, $\mathrm{H}_{2} \mathrm{O}_{2}$ induced STAT- 6 phosphorylation by activating SFKs via lipid rafts in the T cells. The lipid rafts of T cells are known to be highly enriched with SFKs, and the tyrosine kinase activity of SFKs is essential for T cell activation [46]. This 


\section{Cellular Physiology Cell Physiol Biochem 2017;42:2467-2480 \begin{tabular}{ll|l} 
DOI: 10.1159/000480210 & 20 2017 The Author(s). Published by S. Karger AG, Basel \\
www.karger.com/cpb
\end{tabular} \\ Kim et al.: $\mathrm{H}_{2} \mathrm{O}_{2}$ Activates STAT-6 in T Cells}

is consistent with our data showing that ROS-induced STAT-6 phosphorylation occurs in a SFKs-dependent manner, and intact lipid rafts are required for these processes.

STAT-6 phosphorylation and translocation were abolished by $M \beta C D$, a cholesteroldepleting agent, suggesting that intact rafts are required for $\mathrm{H}_{2} \mathrm{O}_{2}$-induced oxidative stressmediated regulation of STAT-6 [33]. Lipid rafts are membrane microdomains formed by high concentrations of sphingolipids and cholesterol immersed in a phospholipid-rich environment [46]. In the resting state in T cells, membrane proteins such as CD3 and CD4 are associated with small lipid rafts. Following T cell activation by anti-CD3 antibody, lipid rafts concentrate in the immunological synapse, gathering specific membrane proteins [46]. In our system, T cells exposed to exogenous ROS showed enhanced phosphorylation of STAT6 , and in T cells this phosphorylation was enhanced by assembly of lipid rafts in the presence of anti-CD3 antibody. This is consistent with previous studies showing that Th2-dominated responses were developed under conditions of different types of antigen or extent of TCR ligation [46]. Previous reports have shown that ROS-induced oxidative stress is another stimulus that activates several signaling events via lipid rafts [33]. We demonstrated that $\mathrm{H}_{2} \mathrm{O}_{2}$ alone can promote STAT- 6 phosphorylation through lipid rafts and the extent of STAT6 activation depends on the status of lipid rafts. Our results also suggest that ROS and TCR activation can potentiate STAT- 6 phosphorylation, IL-4 production, and the generation of Th2 cells in vitro. This synergistic effect of ROS and TCR activation may play a role in the development of the $\mathrm{T}$ cell repertoire towards the Th2 phenotype and in numerous diseases where oxidative stress or antigen exposure potentially play a crucial role, including asthma and allergy as well as autoimmune diseases.

We demonstrated that activation of STAT- 6 by exogenous $\mathrm{H}_{2} \mathrm{O}_{2}$ affects IL- 4 mRNA expression and these processes occur via lipid rafts and are enhanced by anti-CD3 antibody. Unlike IL-4, $\mathrm{H}_{2} \mathrm{O}_{2}$ activates STAT-6 via the SFKs pathway, which participates in regulation of IL-4 expression. STAT- 6 activation by exogenous ROS stimulates IL-4 expression and the increase in IL-4 subsequently re-activates STAT- 6 in T cells, promoting and regulating the further increase in IL-4 and Th2 differentiation. Therefore, our results suggest that, in the Th2 differentiation process, ROS might act on upstream and initiating factors for activation of STAT- 6 and in the formation of a positive feedback loop between STAT- 6 and IL- 4 in T cells.

\section{Abbreviations}

ROS (Reactive Oxygen Species); STAT-6 (Signal Transducer and Activator of Transcription-6); $\mathrm{H}_{2} \mathrm{O}_{2}$ (Hydrogen Peroxide); $\mathrm{M} \beta \mathrm{CD}$ (Methyl- $\beta$-Cyclodextrin); TCR (T cell Receptor); SFKs (Src family kinases);

\section{Acknowledgements}

This work was supported by ther National Research Foundation of Korea (NRF) grant funded by the Korean government (MSIP) [Grant 2010-0027945].

\section{Disclosure Statement}

The authors declare no conflict of interest.

\section{References}

1 Mittal M, Siddiqui MR, Tran K, Reddy SP, Malik AB: Reactive oxygen species in inflammation and tissue injury. Antioxid Redox Signal 2014;20:1126-1167.

-2 Biswas SK: Does the Interdependence between Oxidative Stress and Inflammation Explain the Antioxidant Paradox? Oxid Med Cell Longev 2016;2016:5698931. 


\section{Cellular Physiology Cell Physiol Biochem 2017;42:2467-2480

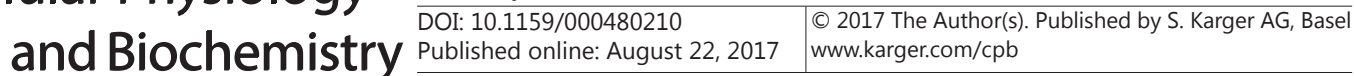 \\ Kim et al.: $\mathrm{H}_{2} \mathrm{O}_{2}$ Activates STAT-6 in T Cells}

-3 Yang Y, Bazhin AV, Werner J, Karakhanova S: Reactive oxygen species in the immune system. Int Rev Immunol 2013;32:249-270.

4 Chen X, Song M, Zhang B, Zhang Y: Reactive Oxygen Species Regulate T Cell Immune Response in the Tumor Microenvironment. Oxid Med Cell Longev 2016;2016:1580967.

5 Paul WE, Zhu J: How are T(H)2-type immune responses initiated and amplified? Nat Rev Immunol 2010;10:225-235.

6 Maier E, Duschl A, Horejs-Hoeck J: STAT6-dependent and -independent mechanisms in Th2 polarization. Eur J Immunol 2012;42:2827-2833.

7 Raphael I, Nalawade S, Eagar TN, Forsthuber TG: T cell subsets and their signature cytokines in autoimmune and inflammatory diseases. Cytokine 2015;74:5-17.

-8 Angkasekwinai P, Park H, Wang YH, Wang YH, Chang SH, Corry DB, Liu YJ, Zhu Z, Dong C: Interleukin 25 promotes the initiation of proallergic type 2 responses. J Exp Med 2007;204:1509-1517.

-9 Xu D, Chan WL, Leung BP, Huang F, Wheeler R, Piedrafita D, Robinson JH, Liew FY: Selective expression of a stable cell surface molecule on type 2 but not type 1 helper T cells. J Exp Med 1998;187:787-794.

10 Lohning M, Stroehmann A, Coyle AJ, Grogan JL, Lin S, Gutierrez-Ramos JC, Levinson D, Radbruch A, Kamradt T: T1/ST2 is preferentially expressed on murine Th2 cells, independent of interleukin 4, interleukin 5, and interleukin 10, and important for Th2 effector function. Proc Natl Acad Sci U S A 1998;95:6930-6935.

11 Schmitz J, Owyang A, Oldham E, Song Y, Murphy E, McClanahan TK, Zurawski G, Moshrefi M, Qin J, Li X, Gorman DM, Bazan JF, Kastelein RA: IL-33, an interleukin-1-like cytokine that signals via the IL-1 receptorrelated protein ST2 and induces T helper type 2-associated cytokines. Immunity 2005;23:479-490.

-12 He R, Oyoshi MK, Garibyan L, Kumar L, Ziegler SF, Geha RS: TSLP acts on infiltrating effector T cells to drive allergic skin inflammation. Proc Natl Acad Sci U S A 2008;105:11875-11880.

13 Chapoval S, Dasgupta P, Dorsey NJ, Keegan AD: Regulation of the T helper cell type 2 (Th2)/T regulatory cell (Treg) balance by IL-4 and STAT6. J Leukoc Biol 2010;87:1011-1018.

-14 Dwivedi G, Gran MA, Bagchi P, Kemp ML: Dynamic Redox Regulation of IL-4 Signaling. PLoS Comput Biol 2015;11:e1004582.

15 Benekli M, Baer MR, Baumann H, Wetzler M: Signal transducer and activator of transcription proteins in leukemias. Blood 2003;101:2940-2954.

16 Varshney P, Yadav V, Saini N: Lipid rafts in immune signalling: current progress and future perspective. Immunology 2016;149:13-24.

17 Simons K, Sampaio JL: Membrane organization and lipid rafts. Cold Spring Harb Perspect Biol 2011;3:a004697.

18 Zaas DW, Duncan M, Rae Wright J, Abraham SN: The role of lipid rafts in the pathogenesis of bacterial infections. Biochim Biophys Acta 2005;1746:305-313.

19 Abbas W, Herbein G: Plasma membrane signaling in HIV-1 infection. Biochim Biophys Acta 2014;1838:1132-1142.

-20 Yang N, Huang Y, Jiang J, Frank SJ: Caveolar and lipid raft localization of the growth hormone receptor and its signaling elements: impact on growth hormone signaling. J Biol Chem 2004;279:20898-20905.

-21 Bramkamp M, Lopez D: Exploring the existence of lipid rafts in bacteria. Microbiol Mol Biol Rev 2015;79:81-100.

-22 Das S, Chakraborty S, Basu A: Critical role of lipid rafts in virus entry and activation of phosphoinositide 3' kinase/Akt signaling during early stages of Japanese encephalitis virus infection in neural stem/progenitor cells. J Neurochem 2010;115:537-549.

23 Lu SP, Lin Feng MH, Huang HL, Huang YC, Tsou WI, Lai MZ: Reactive oxygen species promote raft formation in T lymphocytes. Free Radic Biol Med 2007;42:936-944.

24 Gajate C, Mollinedo F: Lipid rafts and raft-mediated supramolecular entities in the regulation of CD95 death receptor apoptotic signaling. Apoptosis 2015;20:584-606.

25 Nadiri A, Polyak MJ, Jundi M, Alturaihi H, Reyes-Moreno C, Hassan GS, Mourad W: CD40 translocation to lipid rafts: signaling requirements and downstream biological events. Eur J Immunol 2011;41:2358-2367.

26 Hofman EG, Ruonala MO, Bader AN, van den Heuvel D, Voortman J, Roovers RC, Verkleij AJ, Gerritsen HC, van Bergen En Henegouwen PM: EGF induces coalescence of different lipid rafts. J Cell Sci 2008;121:25192528.

27 Legler DF, Micheau 0, Doucey MA, Tschopp J, Bron C: Recruitment of TNF receptor 1 to lipid rafts is essential for TNFalpha-mediated NF-kappaB activation. Immunity 2003;18:655-664. 


\section{Cellular Physiology Cell Physiol Biochem 2017;42:2467-2480 \begin{tabular}{l|l|l} 
DOI: 10.1159/000480210 & and Biochemistry Published online: August 22, 2017 & $\begin{array}{l}\text { O 2017 The Author(s). Published by S. Karger AG, Basel } \\
\text { www.karger.com/cpb }\end{array}$ \\
\cline { 2 - 3 } &
\end{tabular} \\ Kim et al.: $\mathrm{H}_{2} \mathrm{O}_{2}$ Activates STAT- 6 in T Cells}

-28 Thomas S, Kumar RS, Brumeanu TD: Role of lipid rafts in T cells. Arch Immunol Ther Exp (Warsz) 2004;52:215-224.

29 Filipp D, Ballek 0, Manning J: Lck, Membrane Microdomains, and TCR Triggering Machinery: Defining the New Rules of Engagement. Front Immunol 2012;3:155.

- 30 Fruman DA, Pai SY, Burakoff SJ, Bierer BE: Characterization of a mutant calcineurin A alpha gene expressed by EL4 lymphoma cells. Mol Cell Biol 1995;15:3857-3863.

-31 Kim HR, Lee A, Choi EJ, Kie JH, Lim W, Lee HK, Moon BI, Seoh JY: Attenuation of experimental colitis in glutathione peroxidase 1 and catalase double knockout mice through enhancing regulatory $\mathrm{T}$ cell function. PLoS One 2014;9:e95332.

32 Jo A, Park H, Lee SH, Ahn SH, Kim HJ, Park EM, Choi YH: SHP-2 binds to caveolin-1 and regulates Src activity via competitive inhibition of CSK in response to H2O2 in astrocytes. PLoS One 2014;9:e91582.

33 Park SJ, Kim HY, Kim H, Park SM, Joe EH, Jou I, Choi YH: Oxidative stress induces lipid-raft-mediated activation of Src homology 2 domain-containing protein-tyrosine phosphatase 2 in astrocytes. Free Radic Biol Med 2009;46:1694-1702.

-34 Choi YH, Bernardi R, Pandolfi PP, Benveniste EN: The promyelocytic leukemia protein functions as a negative regulator of IFN-gamma signaling. Proc Natl Acad Sci U S A 2006;103:18715-18720.

35 Shin EC, Park SH, Demino M, Nascimbeni M, Mihalik K, Major M, Veerapu NS, Heller T, Feinstone SM, Rice CM, Rehermann B: Delayed induction, not impaired recruitment, of specific CD8(+) T cells causes the late onset of acute hepatitis C. Gastroenterology 2011;141:686-695, 695 e681.

-36 Yun JH, Park SJ, Jo A, Kang JL, Jou I, Park JS, Choi YH: Caveolin-1 is involved in reactive oxygen speciesinduced SHP-2 activation in astrocytes. Exp Mol Med 2011;43:660-668.

-37 Park SJ, Lee JH, Kim HY, Choi YH, Park JS, Suh YH, Park SM, Joe EH, Jou I: Astrocytes, but not microglia, rapidly sense $\mathrm{H}(2) \mathrm{O}(2)$ via STAT6 phosphorylation, resulting in cyclooxygenase-2 expression and prostaglandin release. J Immunol 2012;188:5132-5141.

38 Huang SC, Tsai HF, Tzeng HT, Liao HJ, Hsu PN: Lipid raft assembly and Lck recruitment in TRAIL costimulation mediates NF-kappaB activation and T cell proliferation. J Immunol 2011;186:931-939.

39 Leitenberg D, Balamuth F, Bottomly K: Changes in the T cell receptor macromolecular signaling complex and membrane microdomains during T cell development and activation. Semin Immunol 2001;13:129-138.

40 Dykstra M, Cherukuri A, Pierce SK: Rafts and synapses in the spatial organization of immune cell signaling receptors. J Leukoc Biol 2001;70:699-707.

-41 Hebenstreit D, Wirnsberger G, Horejs-Hoeck J, Duschl A: Signaling mechanisms, interaction partners, and target genes of STAT6. Cytokine Growth Factor Rev 2006;17:173-188.

42 Walford HH, Doherty TA: STAT6 and lung inflammation. JAKSTAT 2013;2:e25301.

-43 King MR, Ismail AS, Davis LS, Karp DR: Oxidative stress promotes polarization of human T cell differentiation toward a T helper 2 phenotype. J Immunol 2006;176:2765-2772.

-44 Rosanna DP, Salvatore C: Reactive oxygen species, inflammation, and lung diseases. Curr Pharm Des 2012;18:3889-3900.

45 Jang JY, Rhee JY, Chung GC, Kang H: Aquaporin as a membrane transporter of hydrogen peroxide in plant response to stresses. Plant Signal Behav 2012;7:1180-1181.

- 46 Alonso MA, Millan J: The role of lipid rafts in signalling and membrane trafficking in T lymphocytes. J Cell Sci 2001;114:3957-3965. 